\title{
INDUSTRIAL DESIGN EDUCATION IN NIGERIA TODAY: CHALLENGES FOR THE 21ST CENTURY LEARNERS
}

\author{
Oluwafemi S. ADELABU ${ }^{1}$ and Olusegun A. FATUYI ${ }^{2}$ \\ ${ }^{1}$ Department of Industrial Design, University of Johannesburg, South Africa \\ ${ }^{1 \& 2}$ Industrial Design Department, Federal University of Technology Akure, Nigeria
}

\begin{abstract}
In an era of a rapid technological advancement amidst unprecedented societal transformation, there is an increasing need for an appropriate response in higher education to equip learners with the right knowledge, skills and attitude. A critical look on the role of design education for the $21^{\text {st }}$ Century has raised the need to question the current state of industrial design education in Nigeria towards identifying gaps that must be filled to effectively prepare students for the $21^{\text {st }}$ Century skills demand. This study examines the existing structure of industrial design education in Nigeria in the lights of its curricular content and explores the skills gap for the $21^{\text {st }}$ Century learners through graduates' self-assessment feedbacks. Both quantitative and qualitative methods were employed for data collection and analysis. Primary data was collected through an e-questionnaire administered to graduating students of industrial design programmes from selected higher institutions in Nigeria. Secondary data was obtained through a thematic review of curricular content of the industrial design programme as approved by the Nigerian National Universities Commission (NUC). The study outcome revealed the core components of the curriculum and graduates' self-rating of their competence using twelve classifications of evolving skill sets for job readiness in the $21^{\text {st }}$ Century.
\end{abstract}

Keywords: Industrial design education, curriculum, graduates' self-assessment, $21^{\text {st }}$ Century skills

\section{INTRODUCTION}

Industrial Design (ID) today can be viewed as a discipline which is of value to nurturing creative talents, however, challenging the socio-economic and technological realities of the $21^{\text {st }}$ Century in emerging societies will necessitate acquiring timely knowledge and relevant skills. Given that design is a veritable tool for driving social-economic transformation and confronting the challenges for sustainable development, the need to redefine the curriculum of design education in less developed countries is clear. Moreover, since higher learning transformation for the fourth Industrial Revolution (4IR) is now imperative [1], it must be ensured that the curricular framework of design education in higher institutions meet the expectations of the digital era [2]. Lapses in the curriculum framework would create skills gaps that transpire into incompetence's in the workplace. The goal, content and method of delivery of design curriculum must, therefore, inculcate essential components that will amount to appropriate knowledge building and skill development. Today, the $21^{\text {st }}$ Century skills cover skills and learning expectations required for learners in the $21^{\text {st }}$ Century society and workplaces [3], [4].

While many studies have demonstrated a growing need to rethink the future of design education [5][8], very few studies exist that have considered addressing critical issues in ID education in Nigeria today especially in the purview of assessing its graduate competencies and readiness for the changing nature of work. Nigeria as the most populous nation in Africa is still largely faced with myriads of sociopolitical issues hampering the development of an enabling environment for actualizing a vibrant educational system. With no exception for ID education, there is a growing need to revisit the underlying structure and especially the curricular design for the programme towards enhancing the institutional capacity to deliver graduates that can rise to the work demands of the $21^{\text {st }}$ Century. 


\subsection{Study Goal}

This study aimed at evaluating the ID education in Nigeria in the light of the readiness of its graduates to face the challenges of the work demands in the $21^{\text {st }}$ Century. The core questions raised by the study were:

1. What are the key curricular components of ID programmes in Nigeria?

2. What is the self-perception of the Nigerian ID graduates with regards to their competencies on the $21^{\text {st }}$ Century skills?

\section{INDUSTRIAL DESIGN IN NIGERIAN HIGHER INSTITUTIONS}

The Hope Waddell Training Institute established in 1895 was known to be the first institute in Nigeria where courses related to problem-solving were taught under the art and craft curriculum [9]. Later in 1934, Yaba College was established in Lagos (converted to a Technical Institute in 1945) where relevant courses were also introduced. Notably, the University College was created in 1952 with three branches known as the College of Arts, Science and Technology. These institutions later formed the core of the first-generation universities in Nigeria, namely the University of Nigeria, Nsukka (UNN), Ahmadu Bello University, Zaria (ABU) and the University of Ife (now Obafemi Awolowo University, Ile-Ife). Ahmadu Bello University emerged as the first Nigerian university where the ID programme was introduced in 1977 as an offshoot of fine arts programme established earlier in the school [10], [11]. As a result of various government pronouncements, other universities referred to as 2nd and 3rd generation universities sprang up. Among these universities, twelve offer related courses in fine and applied arts while only four institutions adopted the ID nomenclature [12]. Having been conceived out of a nucleus of Fine Arts programme, ID became offered as interdisciplinary art-related programmes which mainly encompasses ceramics, graphics and textile designs (see Table 1 for public universities, mostly including some Nigerian Universities of Technology, currently offering the ID programme with their areas of specialisation).

With the commencement of the ID programme in more Universities in Nigeria, the National Universities Commission (NUC) drew up with a curricular benchmark for the programme in 1999. The basic philosophy of ID degree programme set for the Nigerian universities is to produce "competent skilled and creative individuals capable of upholding, sustaining, and linking educational experiences to the values and needs of the Nigerian society" [13]. Although the objectives as set by the National Universities Commission appear straightforward, its appropriateness to training competent graduates for the $21^{\text {st }}$ Century society and workplaces is yet to be critically evaluated. Yang, You and Han [14] suggested that universities should continuously renew the ID curriculum and encourage interdisciplinary interactions to enhance the ability of students to succeed in the future workplace.

Table 1. Selected Universities offering ID programmes in Nigeria

\begin{tabular}{|c|l|l|l|l|}
\hline & University & $\begin{array}{l}\text { Year } \\
\text { founded }\end{array}$ & $\begin{array}{l}\text { Type of } \\
\text { ownership }\end{array}$ & $\begin{array}{l}\text { Programme degree and areas of } \\
\text { specialisation }\end{array}$ \\
\hline 1. & Ahmadu Bello University (ABU) & 1962 & $\begin{array}{l}\text { Federal } \\
\text { government- } \\
\text { owned }\end{array}$ & $\begin{array}{l}\text { Industrial Design (B.A., B.Sc.) } \\
\text { Ceramics, Graphics, Textiles, } \\
\text { Glass Technology }\end{array}$ \\
\hline 2. & $\begin{array}{l}\text { Abubakar Tafawa Balewa University, } \\
\text { Bauchi (ATBU) }\end{array}$ & 1980 & $\begin{array}{l}\text { Federal } \\
\text { government- } \\
\text { owned }\end{array}$ & $\begin{array}{l}\text { Industrial Design (B.Tech.) } \\
\text { Ceramics Technology; Graphics } \\
\text { Technology; Metal and Jewellery }\end{array}$ \\
\hline 3. & $\begin{array}{l}\text { Federal University of Technology, } \\
\text { Akure (FUTA) }\end{array}$ & 1981 & $\begin{array}{l}\text { Federal } \\
\text { government- } \\
\text { owned }\end{array}$ & $\begin{array}{l}\text { Industrial Design (B.Tech.) } \\
\text { Graphic Design, Textile Design } \\
\text { and Ceramics }\end{array}$ \\
\hline 4. & $\begin{array}{l}\text { Modibbo Adama University of } \\
\text { Technology, Yola (MAUTECH, } \\
\text { formerly Federal University of } \\
\text { Technology, Yola) }\end{array}$ & 1981 & $\begin{array}{l}\text { Federal } \\
\text { government- } \\
\text { owned }\end{array}$ & $\begin{array}{l}\text { Industrial Design (B.Tech.) } \\
\text { Graphic Design, Textile Design } \\
\text { and Ceramics }\end{array}$ \\
\hline 5. & $\begin{array}{l}\text { Ladoke Akintola University of } \\
\text { Technology (LAUTECH) }\end{array}$ & 1990 & $\begin{array}{l}\text { State } \\
\text { government- } \\
\text { owned }\end{array}$ & $\begin{array}{l}\text { B.A., B.Tech } \\
\text { Graphic Design, Textile Design, } \\
\text { Ceramics }\end{array}$ \\
\hline
\end{tabular}




\section{HIGHER EDUCATION AND THE 21ST CENTURY SKILLS IMPERATIVE}

There is a growing concern that the skills set required in a time of rapidly changing world amidst unprecedented socio-economic and ecological challenges will necessitate an appropriate response by higher education in the way learners are being trained for the world of work. Especially, the potential impact of the 4IR technologies on the way humans live, learn and work is seen as a potent force for economic transformation and social development [15], [16]. The drive for assimilating fast-evolving technologies and the imperative of acquiring the $21^{\text {st }}$ Century skills is thus questioning the state of the current educational system. Considering the realities of social and demographic issues which requires a high level of critical thinking and complex problem-solving skills, there is an increasing need for an appropriate response in higher education to equip learners with the right knowledge, skills and attitude. The WEF reports [17], [18] emphasized the importance of reskilling and upskilling to adapt to the changing nature of work in the $21^{\text {st }}$ Century. Proficiency in new technologies and "human skills" such as creativity, originality and initiative, critical thinking, persuasion and negotiation among others were highlighted as prominent job demand by 2022 .

Nigeria, with approximately 200 million people, has a burgeoning youth population [19] but its rising youth unemployment rate with almost 20 percent in 2019 of people within the age group of 15 to 24 years [20], are pointers to the need to reappraise its education system. While this demographic growth might be an advantage for a productive society, it poses a challenge for the higher education in the country demanding integration of relevant knowledge and skill development across its educational strata. Against this development, the workplace is increasingly being redefined by competitive skill sets which are largely defined by the $21^{\text {st }}$ Century skills. It is expected that this skills set are required for jobs that are locally relevant and yet globally competitive. This outlook inevitably calls for changes in education, particularly higher education, which cannot afford to overlook the new realities. Despite the high demand for educational opportunities for its youth population, Nigeria's higher education system is still today faced with the challenge of being underfunded amidst severe cuts in governmental aid following a nationwide recession in 2016 [21] and the impact of the COVID-19 pandemic in 2020. The issue of 'brain drain' persists as Nigeria is noted as a top country of origin for international students from the continent of Africa. Whether the gains of building human capacity outside of the country would be an advantage towards bridging its skill demand for jobs and development within the nation remains to be seen.

\section{METHODOLOGY}

This study adopted both qualitative and quantitative approaches for data collection. The qualitative method involved an evaluation of the basic components of ID curriculum in Nigeria based on the approved framework by the NUC [13]. The quantitative method employed the use of a semi-structured e-questionnaire designed with SoGoSurvey and administered online to graduates of ID programmes in Nigeria. The study is delimited by the number of responses received and the available information on the ID programme curriculum as offered currently in key Nigerian higher institutions. The curricular data were characterised using thematic analysis [22] while the survey responses were analysed through descriptive statistics.

\section{KEY FINDINGS AND DISCUSSION}

Using the data drawn from the programme curricula and graduate survey responses, the study documents and discusses key findings on the basic components of ID curriculum in Nigeria and the self-assessment of ID graduates on their level of competency on the $21^{\text {st }}$ Century. Twelve (12) classifications of emerging skill sets were adopted from the World Economic Forum (WEF) 2018 Report on the Future of Jobs based on the Occupational Information Network (O*NET) framework [17].

\subsection{Respondents' profile}

A population of more than 500 graduates of ID programmes in Nigeria was reached through various web-based platforms. However, responses to the survey were only provided by 63 graduates of 3 out of 5 institutions with dominant responses gotten from graduates of FUTA (88.7\%). The demographic characteristics of respondents are shown in Table 2. 


\begin{tabular}{|c|c|c|c|}
\hline Characteristics & Description & Frequency & Percentage \\
\hline \multirow[t]{2}{*}{ Gender } & Male & 52 & 84 \\
\hline & Female & 10 & 16 \\
\hline \multirow{3}{*}{ Universities attended } & $\mathrm{ABU}$ & 6 & 9.7 \\
\hline & FUTA & 55 & 88.7 \\
\hline & ATBU & 1 & 1.6 \\
\hline \multirow[t]{6}{*}{ Year of Graduation (Range) } & $2015-2019$ & 32 & 51.6 \\
\hline & $2010-2014$ & 21 & 33.9 \\
\hline & $2005-2009$ & 4 & 6.5 \\
\hline & $2000-2004$ & 3 & 4.8 \\
\hline & $1995-1999$ & 1 & 1.6 \\
\hline & $1985-1989$ & 1 & 1.6 \\
\hline \multirow[t]{6}{*}{ Employment status } & Self-employed & 25 & 40.3 \\
\hline & Employed in a company (permanent) & 17 & 27.4 \\
\hline & Employed in a company (temporary) & 9 & 14.5 \\
\hline & Institution & 9 & 14.5 \\
\hline & Unemployed & 1 & 1.6 \\
\hline & Missing value & 1 & 1.6 \\
\hline \multirow[t]{14}{*}{ Nature of current job } & Advertising \& Marketing & 10 & 16.1 \\
\hline & Business Support Services & 1 & 1.6 \\
\hline & Construction & 1 & 1.6 \\
\hline & Education & 17 & 27.4 \\
\hline & Fashion Designing & 2 & 3.2 \\
\hline & Financial Services & 5 & 8.1 \\
\hline & Health Care & 1 & 1.6 \\
\hline & Information Technology Services & 3 & 4.8 \\
\hline & Product Design and Dev. & 2 & 3.2 \\
\hline & Professional Services & 4 & 6.5 \\
\hline & Real Estate & 1 & 1.6 \\
\hline & Transport \& Logistic Services & 1 & 1.6 \\
\hline & Textile Production & 1 & 1.6 \\
\hline & Others & 12 & 20 \\
\hline
\end{tabular}

\subsection{Basic components of the ID curriculum}

The design of the curricular content for ID programmes broadly covers core and supplementary subjects in specialised areas which include Ceramics, Graphics and Textile designs. The key components of the curriculum can be classified into two main categories:

(i.) General Knowledge and Skills

(ii.) Specialised Knowledge and Skills

The component for General Knowledge and Skills for ID disciplines cover course contents that provide the students with holistic development. This appears to foster broad-based knowledge through subjects that cut across general studies, science and engineering education, information technology and tools, communication skills, academic writing and presentation skills, project management, historical and cultural studies, fundamentals of design, and entrepreneurship education. On the other hand, the component for Specialised Knowledge and Skills appears in form of courses offered to equip students with professional knowledge, hands-on skills, practical and attitude to develop competencies and workreadiness in specific areas of specialisation. Hands-on experiences are provided through studio-based practical works, industrial visit, internship, portfolio development and problem-solving project works. Considering the nature of training required for ID education as a vocational and multidisciplinary field, it is expected that the curriculum will not only require a balanced share of courses focusing on general education but also emphasizing practical skill development. For effective ID training, the summative components of the curriculum must provide appropriate knowledge, skills and attitude fit to address complex societal problems and responsive to the work challenges of the $21^{\text {st }}$ Century. According to Friedman [23], design can be seen as "a process targeted towards solving problems, meeting needs, improving situations, or creating something new or useful". Even though design offers potentials and tools promote creative problem-solving skills, however, the practice of design is broadly shaped by the way it is taught which determines whether designers being trained are capable of dealing with such complexities [24]. 


\subsection{Graduates' self-perceived competency on the $21^{\text {st }}$ Century skills}

From the descriptive analysis of the responses from ID graduates based on their self-evaluation with 12 identified $21^{\text {st }}$ Century skill sets, the overall weighted score of their rating is 3.37 (Figure 1). This is a little above average and could suggest a need to constantly review the curricular design to enable learners to thrive in an evolving landscape of the $21^{\text {st }}$ Century workplace. This is also critical towards enhancing graduate employability in a highly competitive marketplace. It is noteworthy that from the criteria listed for the self-evaluation, the rating of their competency in terms of 'creativity, originality and initiative' ranked highest while their rating of 'technology design and programming' was the lowest with an average weighted score of 3.95 (SD 0.78) and 2.73 (SD 1.133) respectively. While creativity can naturally be emphasized in ID education, the need for digital technological integration in current ID programmes could improve learners' competence for the workplace. This also requires provision stateof-art learning facilities as previous studies have reported a lack of adequate equipment and facilities in universities offering ID in Nigeria [25], [26]. While the results of the evaluation are based on a subjective assessment, the thematic analysis of responses from an open-ended question reveals the impression of the graduates on the need for inclusion of more technical skills and contents that are relevant to the current work demands.

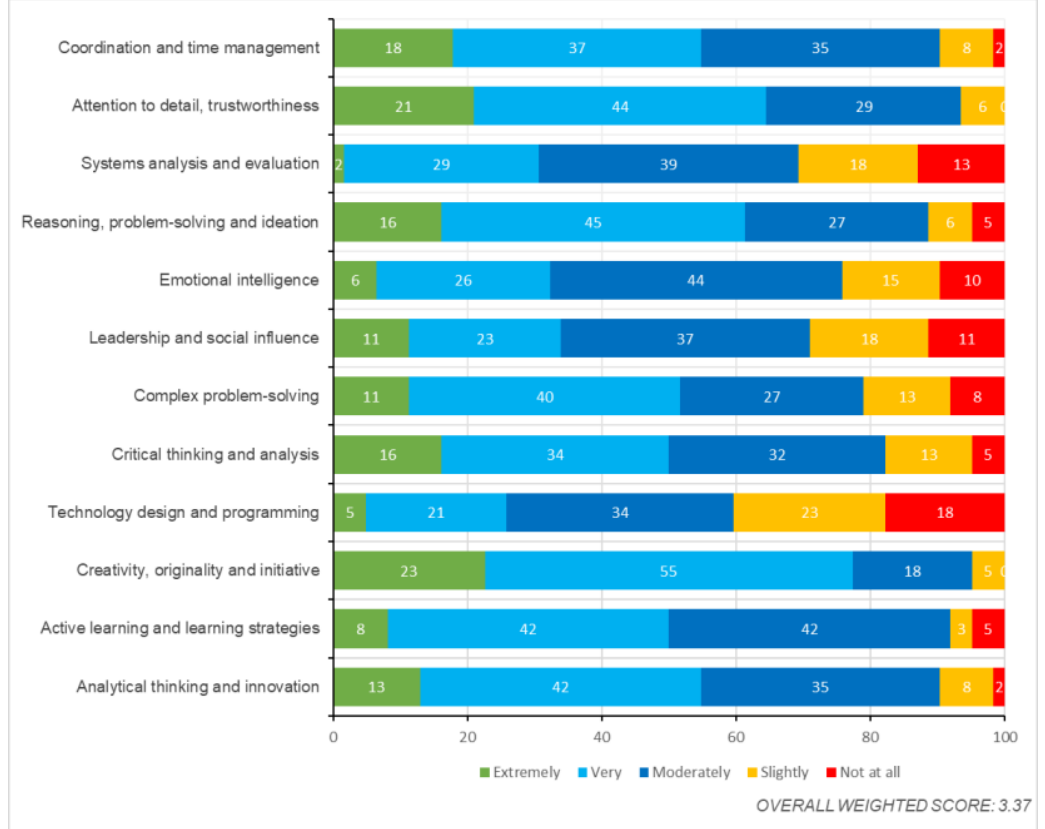

Figure 1. A self-evaluation of the respondents of their competency in the $21^{\text {st }}$ Century skills

\section{CONCLUSIONS}

This study has attempted to examine the curricular components of ID education in Nigeria and the skills gap for the $21^{\text {st }}$ Century learners. In ensuring that the quality of training for ID programmes in Nigeria, the curricular orientation and learning outcome must be enhanced for graduates' competency building towards lifelong self-sustenance and employability in the workplace.

\section{ACKNOWLEDGEMENT}

The authors wish to acknowledge the Global Excellence Stature (GES) 4.0 Funding for Postdoctoral Research for providing the support necessary to conduct this research.

\section{REFERENCES}

[1] Penprase, B.E., The Fourth Industrial Revolution and Higher Education, Higher Education in the Era of the Fourth Industrial Revolution, N. W. Gleason, Ed. London: Palgrave Macmillan, 2018, pp. 207-229.

[2] Adelabu, O.S., Akinbogun, T.L., and Odewole, P.O., Design education in Nigeria: The place of Fourth industrial revolution, Visual Communication Design Conference 2019. Design in the Nigerian Context: Evolving Indigenous Design Approaches, Concepts, Praxis and Education, 2019, pp. 565-586. 
[3] Bellanca, J., and Brandt, R., $21^{\text {st }}$ Century skills: rethinking how students learn. Bloomington, IN: Solution Tree Press, 2010.

[4] Trilling, B., and Fadel, C., $21^{\text {st }}$ Century skills: Learning for life in our times. New York: JosseyBass, 2009.

[5] Findeli, A., Rethinking design education for the $21^{\text {st }}$ Century: Theoretical, methodological, and ethical discussion, Des. Issues, vol. 17, no. 1, pp. 5-17, 2001.

[6] Wright, N., Davis, R., and Bucolo, S., The creative citizen: understanding the value of design education programs in the knowledge economy," $2^{\text {nd }}$ International Conference for Design Education Researchers (DRS//CUMULUS Oslo May 2013), 2013, pp. 14-17.

[7] Novoa, M., Innovating industrial design curriculum in a knowledge-based, participatory and digital era, Des. Technol. Educ., vol. 23, no. 3, pp. 154-204, 2018.

[8] Oygür Ilhan, I. and Karapars, Z.G., Industrial Design Education in the Age of Digital Products, Des. J., vol. 22, no. sup1, pp. 1973-1982, 2019, doi: 10.1080/14606925.2019.1594922.

[9] Taylor, W.H., Mission to educate: A history of the educational work of the Scottish Presbyterian Mission in East Nigeria 1846-1960. Leiden, Netherlands: E.J. Brill, 1996.

[10] Akinbogun, T.L., Preface, Visual Communication Design Conference 2019. Design in the Nigerian Context: Evolving Indigenous Design Approaches, Concepts, Praxis and Education, 2019, pp. 4-6.

[11] Department of Industrial Design Ahmadu Bello University, History - Department of Industrial Design, 2020. [Online]. Available: https://industrialdesign.abu.edu.ng/pages/history.html. [Accessed: 09-Mar-2020].

[12] Akinbogun, T.L. and Ogunduyile, S.R, S.R., History, concept and curriculum of Industrial Design in Nigerian tertiary institutions, Des. Princ. Pract. An Int. J., vol. 3, no. 3, pp. 83-96, 2009.

[13] National Universities Commission, Benchmark minimum academic standards for undergraduate programmes in Nigerian universities: Environmental science (Draft). 2014.

[14] Yang, M.Y., You, M., and Han, C.Y., A study of industrial design students' employment preparation and choices in Taiwan, J. Art, Des. Commun. High. Educ., vol. 9, no. 1, pp. 21-40, 2010, doi: 10.1386/adch.9.1.21.

[15] Schwab, K., The Fourth Industrial Revolution. Davos: World Economic Forum, 2016.

[16] Xing, B. and Marwala, T., Implications of the Fourth Industrial Age on higher education, Thinker, vol. 73, pp. 10-15, 2006.

[17] World Economic Forum (WEF), The Future of Jobs Report 2018, 2018.

[18] WEF, Accelerating workforce reskilling for the Fourth Industrial Revolution: An agenda for leaders to shape the future of education, gender and work, World Econ. Forum White Pap., no. July, p. 22, 2017.

[19] UNDP, Policy brief-Nigeria's Youth Bulge - From Potential 'Demographic Bomb' to 'Demographic Dividend,' 2018. [Online]. Available: https://www.ng.undp.org/content/nigeria/en/home/library/poverty/policy-brief-nigerias-youthbulge--from-potential-demographic-bo.html. [Accessed: 09-Mar-2020].

[20] Statista, Nigeria: Youth unemployment rate from 1999 to 2019, 2019. [Online]. Available: https://www.statista.com/statistics/812300/youth-unemployment-rate-in-nigeria/. [Accessed: 09Mar-2020].

[21] Plecher, H., Youth unemployment rate in Nigeria in 2019, 2020. [Online]. Available: https://www.statista.com/statistics/812300/youth-unemployment-rate-in-nigeria/. [Accessed: 09Mar-2020].

[22] Braun, V. and Clarke, V., Using thematic analysis in psychology, Qual. Res. Psychol., vol. 3, no. 2, pp. 77-101, 2006, doi: http://dx.doi.org/10.1191/1478088706qp063oa.

[23] Friedman, K., Theory construction in design research: Criteria, approaches and methods, Des. Stud., vol. 24, no. 6, pp. 507-522, 2003.

[24] Manzini, E., Small, local, open and connected: Design for social innovation and sustainability, J. Des. Strateg., vol. 4, no. 1, pp. 8-11, 2010.

[25] Adelabu, O.S. and Idowu, S.O., Pursuit of industrial design career in Nigeria: An appraisal of the current trend, J. Ind. Des., vol. 1, no. 2, pp. 1-9, 2011.

[26] Oladumiye, B.E., Fatuyi, O.A. and Ibiwoye, T.P., Forecasting the future of Nigerian Industrial Design education in a global era, Int. J. Res. Soc. Sci., 2018. 